\title{
PENGEMBANGAN MEDIA PEMBELAJARAN AUDIO VISUAL PROGRAM MICROSOFT POWER POINT PADA POKOK BAHASAN ORGANISASI KEHIDUPAN KELAS VIIA SMP NEGERI 19 MATARAM TAHUN PELAJARAN 2012/2013
}

\author{
Ida Ayu Putu Armyani ${ }^{1)}$ dan Didik Martedi ${ }^{2)}$ \\ ${ }^{1,2)}$ SMP Negeri 19 Mataram, J1. Dr. Soedjono Dasan Cermen Kota mataram \\ Email: ayuarmyani@gmail.com
}

\begin{abstract}
Abstrak: Penelitian ini bertujuan untuk meningkatan aktivitas belajar SMP Negeri 19 Mataram dengan menggunakan media audio visual program power point. Program ini dapat memudahkan guru dalam menyampaikan konsep IPA, terutama konsep abstrak menjadi konsep yang konkrit sehingga bisa dinalar siswa, misalnya: organisasi kehidupan. Subyek pada penelitian ini berjumlah 47 siswa kelas VIIA SMP Negeri 19 Mataram. Pengambilan data mengunakan metode observasi, lembar tanggapan dan metode tes.penelitian dilakukan dengan dua siklus. Setiap siklus dilaksanakan dalam dua kali pertemuan. Tahapan tiap siklus meliputi perencanaan, pelaksanaan tindakan, observasi dan refleksi. Hasil penelitian pada siklus I, aktifitas siswa pada Proses Belajar Mengajar (PBM) hanya mencapai 51,06\%, ketuntasan hasil belajar mencapai 68,77\% sedangkan pada siklus II aktifitas siswa pada PBM sudah mengalami peningkatan yaitu mencapai 84,04\%, ketuntasan hasil belajar mencapai $84,26 \%$.
\end{abstract}

Kata Kunci: media, aktivitas belajar, powerpoint.

\begin{abstract}
This study aims to improve learning activities of SMP 19 Mataram students by using audio-visual powerpoint media. The media can facilitate teachers to convey the concept of science, especially the abstract concept into a concrete concept that can be rationalized by students, for example: organization of life. Subjects in this study were 47 students of grade VII of SMPN 19 Mataram. Retrieving data using the method of observation, response sheets and methods tes. This study was conducted in two cycles. Each cycle consisted of two sessions. Each cycle includes the stages of planning, action, observation and reflection. The results showed that at the first cycle, the student activity in learning process was only $51.06 \%$, learning outcomes mastery was $68.77 \%$, while in the second cycle, the students activity wash $84.04 \%$, learning outcomes mastery was 84.26 $\%$.
\end{abstract}

Key words: media, lerning activity, powerpoint

\section{PENDAHULUAN}

Keberhasilan proses pembelajaran di kelas dapat dilihat dari aktivitas belajar siswa sehingga dapat diperoleh nilai sesuai dengan ketuntasan minimal yang telah ditentukan. Berdasarkan hasil observasi awal dan diskusi dengan guru IPA SMP Negeri 19 Mataram, diperoleh bahwa hasil belajar IPA masih rendah (rata- rata 52) dibandingkan dengan Kriteria Ketuntasan Minimal, yaitu 75 . Rendahnya hasil belajar tersebut diduga akibat adanya anggapan bahwa materi IPA bersifat abstrak dan sulit dinalar.

Menyikapi hal tersebut penulis sebagai guru IPA harus berusaha memperbaiki pembelajaran dengan mengkondisikan pembelajaran yang mampu dinalar siswa, mudah diingat, tidak membosankan, efektif, efisien dan meningkatkan kemandirian siswa untuk belajar. Dalam hal ini, diperlukan teknik- teknik tertentu yang dapat digunakan untuk membantu keberhasilan proses belajar mengajar, diantaranya adalah penggunaan media.

Media pembelajaran adalah alat, metode, dan teknik yang digunakan dalam rangka mengefektifkan komunikasi dan interaksi antar guru dan peserta didik dalam proses pendidikan
[2]. Kedudukan media dalam pembelajaran sangat penting yaitu sebagai salah satu upaya untuk mempertinggi proses interaksi guru dengan peserta didik dan interaksi peserta didik dengan lingkungannya, meletakkan dasar-dasar yang kongkrit untuk berfikir sehingga mengurangi verbalisme, memperbesar perhatian peserta didik, meletakkan dasar-dasar yang penting untuk perkembangan belajar, membuat pelajaran lebih mantap, memberikan pengalaman nyata yang dapat menumbuhkan kegiatan belajar di kalangan peserta didik, menumbuhkan berfikir sistematis dan kontinyu, membantu perkembangan kemampuan berbahasa, memberikan pengalaman-pengalaman yang tidak 80ias diperoleh dengan cara lain misalnya ceramah, membantu meningkatkan efisiensi dan keanekaragaman yang lebih banyak dalam belajar [5].

Media yang dapat digunakan sangat beragam diantaranya adalah media pengajaran komputer presentasi program microsoft power point. Program ini dapat memudahkan guru dalam menyampaikan konsep IPA, terutama konsep abstrak menjadi konsep yang konkrit sehingga bisa dinalar siswa, misalnya: organisasi kehidupan. Pada materi ini guru perlu menampilkan beberapa 
gambar untuk menyesuaikan materi dengan pengalaman sehari- hari siswa.

Berdasarkan latar belakang yang telah diuraikan dilakukanlah penelitian dengan judul "pengembangan media pembelajaran audio visual program microsoft power point pada pokok bahasan organisasi kehidupan kelas VIIA SMP Negeri 19 Mataram Tahun Pelajaran 2012/2013”.

\section{METODE PENELITIAN Jenis Penelitian}

Jenis penelitian ini adalah penelitian tindakan kelas (PTK) dengan menerapkan pengembangan media audio visual dengan program microsoft power point dalam pembelajaran biologi. Kenmis dan Taggart [1] menyatakan bahwa model penelitian tindakan adalah berbentuk spiral. Tahapan penelitian tindakan pada suatu siklus meliputi perencanaan atau pelaksanaan observasi dan refleksi. Siklus itu berlanjut dan akan berhenti jika sudah sesuai dengan kebutuhan dan dirasa sudah mencapai hasil yang diharapkan.

\section{Setting Penelitian}

Penelitian ini dilaksanakan pada bulan Februari-April 2013 di kelas VIIA semester satu SMP Negeri 19 Mataram Tahun Pelajaran 2012/2013 dengan jumlah siswa 47 orang. Dalam penelitian ini ada beberapa faktor yang diamati, yaitu terdiri dari (1) Faktor siswa: mengukur aktifitas siswa dan ketuntasan siswa sasaran setelah diberi perlakuan dan (2) Faktor guru: mengukur kemampuan guru dalam merencanakan, menyusun, mengembangkan media pembelajaran, membantu siswa mengatasi kesulitan belajar, menilai proses belajar, dan menilai hasil belajar siswa.

\section{Rancangan Penelitian}

Penelitian tindakan kelas ini terdiri dari dua siklus, masing- masing siklus dilaksanakan sesuai tujuan yang ingin dicapai. Setiap siklus terdiri dari dua kali pertemuan dan setiap selesai satu siklus diadakan tes formatif untuk mengetahui pemahaman siswa terhadap konsep organisasi kehidupan yang sudah dipelajari. Selain itu juga diadakan refleksi untuk mengetahui beberapa kekurangan pada siklus tersebut untuk memperbaiki siklus selanjutnya.

Pelaksanan penelitian tindakan kelas akan dimulai dari siklus I yang pelaksanaannya melalui empat tahap yaitu (1) Perencanaan, yang dibuat berawal dari masalah yang muncul di lapangan yaitu dari pengalaman peneliti sebagai guru di SMP Negeri 19 Mataram. Permasalahan ini dapat disebut sebagai refleksi awal, yaitu hasil belajar yang selalu rendah terutama pada kompetensi dasar tentang organisasi kehidupan. Kegiatan perencanaan diawali dengan mengembangkan silabus, menyusun RPP, dan menyusun instrumen pengamatan dan angket. Rancangan pengembangan media ini menggunakan model 4D (four D models) yang diadaptasi dari Thiagarajan, Semmel, dan Semmel (1979). Model ini terdiri dari empat tahapan, yaitu: define, design, develop, dan disseminate, (2) Pelaksanaan tindakan, Pelaksanaan tindakan dilaksanakan yang tercantum pada lampiran RPP, (3) Observasi, selama proses pembelajaran berlangsung dilakukan observasi oleh observer Didik Martedi, S.Pd, baik terhadap siswa maupun guru, dan (4) Refleksi, Data hasil pengamatan dianalisis secara deskriptif untuk melakukan refleksi yang dilakukan bersama- sama dengan observer untuk melihat kelemahan. Data yang terekam dievaluasi dan diambil kesimpulan untuk membuat rencana pelaksanaan siklus II.

\section{Instrumen Penelitian}

Instrumen penelitian yang digunakan terdiri dari (1) Lembar tanggapan, Merupakan lembar yang digunakan untuk mengumpulkan data mengenai pendapat guru mata pelajaran mengenai media, (2) Lembar observasi, Lembar observasi merupakan lembar yang digunakan observer pada saat PBM berlangsung, (3) Silabus, (4) Rencana pelaksanaan pembelajaran, dan (5) Perangkat tes.

\section{Metode Pengumpulan Data}

Metode yang digunakan dalam pengumpulan data terdiri dari (1) Lembar tanggapan, untuk mengumpulkan data tentang pendapat guru bidang studi tentang kelayakan media yang dikembangkan pada penelitian ini, (2) Metode observasi, digunakan untuk mengumpulkan data proses pembelajaran. Pengamatan dilakukan guru bidang studi mengenai proses pembelajaran menggunakan media, dan (3) Metode tes. Metode ini digunakan untuk mengetahui ketuntasan belajar siswa setelah menggunakan media pembelajaran microsoft power point.

\section{Metode analisis data}

Analisis data penelitian yang digunakan terdiri dari (1) Analisis penilaian kelayakan media. Lembar tanggapan yang telah diisi oleh dosen pembimbing dan guru bidang studi dianalisis secara deskriptif, (2) Analisis hasil pengamatan proses belajar mengajar. Data aktifitas proses pembelajaran, yaitu: minimal $80 \%$ mampu melakukan aktifitas proses pembelajaran, dan (3) Analisis hasil belajar siswa. Data hasil belajar dianalisis berdasarkan pada ketuntasan belajar, yaitu: $100 \%$ siswa mencapai 75 . Dan $80 \%$ tujuan pembelajaran mencapai ketuntasan $80 \%$

\section{HASIL DAN PEMBAHASAN Hasil Penelitian Siklus 1}

Kegiatan perencanaan pada siklus 1 telah dipersiapkan beberapa hal yang diperlukan dalam pelaksanaan penelitian, diantaranya ialah pengembangan media, menyusun RPP, menyusun 
instrumen, dan menetapkan cara refleksi. Tahap pengembangan media terdiri dari (1) tahap pendefinisian. Pada tahap ini dilakukan (a) Analisis kurikulum. Hasil dari analisis ini diperoleh suatu masalah dasar dari KTSP (kurikulum tingkat satuan pendididkan) dengan kompetensi dasar yang dipilih, ialah: Mendeskripsikan keragaman pada sistem organisasi kehidupan mulai dari tingkat sel sampai organisme., (b) Analisis siswa. Siswa kelas VIIA ini, berusia antara 12-14 tahun dengan tingkat kedewasaan yang sesuai dengan siswa seusia mereka. Motivasi siswa terhadap mata pelajaran biologi tidak seragam. Sebagian ada yang tertarik untuk belajar dan sebagian lainnya kurang tertarik. Pengalaman belajar mereka sama yaitu sudah mengenal dan mampu mengoperasikan komputer tetapi belum pernah belajar menggunakan LCD, (c) Analisis tugas. Dari analisis tugas ini diperoleh konsep dan tujuan yang akan dipelajari pada setiap kali pertemuan. Pada pembelajaran organisasi kehidupan, materi disajikan dalam dua kali pertemuan seperti yang tercantum pada lampiran rencana pelaksanaan pembelajaran, (d) Analisis konsep. Analisis konsep dilakukan dengan mengidentifikasi konsep- konsep utama pada materi yang akan diajarkan. Hasil analisis konsep ini berupa peta konsep seperti yang tercantum dalam lampiran media pembelajaran, dan (e) Perumusan tujuan pembelajaran. Dari analisis tujuan pembelajaran didapat tujuan pembelajaran seperti yang tercantum dalam rencana pelaksanaan pembelajaran, (2) Tahap perancangan (design). Pada tahap ini, langkah- langkah yang dilakukan adalah pemilihan media, penyusunan tes, dan Rencana Pelaksanaan Pembelajaran. Kegiatan utama setelah pemilihan media adalah penulisan skrip program, pengadopsian gambar, pembuatan media dan konsultasi dengan guru mata pelajaran IPA (Didik Martedi, S.Pd), dan (3) Tahap pengembangan (develop). Pada tahap ini, diperoleh draft II yaitu hasil revisi yang telah ditelaah oleh guru mata pelajaran IPA dan draft III yaitu hasil revisi draft II yang telah ditelaah kembali oleh guru mata pelajaran IPA mengenai kelayakan media, seperti yang tercantum pada lampiran. Media yang telah direvisi akan diujicobakan kepada siswa.

Pelaksanaan tindakan dilaksanakan pada hari Rabu, tanggal 6 Februari 2013 dimulai pertemuan pertama kemudian dilanjutkan dengan pertemuan kedua pada hari Kamis, 7 Februari 2013. Pelaksanaan pembelajaran disesuaikan dengan RPP. Dari pembelajaran yang dilakukan diperoleh hasil aktivitas guru seperti pada Tabel 1.

Tabel 1. Data aktivitas guru pada PBM

\begin{tabular}{|c|c|c|c|}
\hline \multirow[t]{2}{*}{ No } & \multirow[t]{2}{*}{ Kegiatan } & \multicolumn{2}{|c|}{ Pertemuan } \\
\hline & & 1 & 2 \\
\hline \multirow[t]{4}{*}{1} & Pendahuluan (10 menit) & & \\
\hline & Menggali pengetahuan awal siswa, (5 menit) & 2 & 2 \\
\hline & Memotivasi siswa, (3 menit) & 3 & 3 \\
\hline & Menyampaikan tujuan pembelajaran, (2 menit) & 3 & 3 \\
\hline \multirow[t]{5}{*}{2} & Inti (60 menit) & & \\
\hline & $\begin{array}{l}\text { Membimbing siswa untuk berdiskusi dengan teman sebangku } \\
\text { mengenai materi yang diajarkan. }\end{array}$ & 3 & 3 \\
\hline & Memberikan penilaian keaktifan siswa dalam berdiskusi & 2 & 2 \\
\hline & $\begin{array}{l}\text { Memberikan informasi yang sebenarnya mengenai materi yang } \\
\text { diajarkan }\end{array}$ & 3 & 3 \\
\hline & Meminta siswa untuk mencatat butir- butir penting pada media & 2 & 2 \\
\hline \multirow[t]{2}{*}{3} & Penutup (10 menit) & & \\
\hline & Membimbing siswa membuat rangkuman materi yang diajarkan & 3 & 3 \\
\hline & Skor rata-rata & \multicolumn{2}{|c|}{2,62} \\
\hline
\end{tabular}

Tanggapan dari pengamat terhadap aktivitas guru pada Tabel 1 ialah bahwa hasil pengamatan aktivitas guru dalam PBM mendapat tanggapan yang cukup baik. Akan tetapi ada beberapa hal yang masih mendapat nilai kurang sehinga diperlukan perbaikan pada siklus selanjutnya. Beberapa hal tersebut adalah (1) pada saat guru menggali pengetahuan siswa, keterangan yang diberikan guru kurang mengena sasaran pembelajaran, (2) aktifitas guru dalam membimbing diskusi, (3) aktifitas guru dalam membimbing siswa mencatat butir- butir penting, dan (4) alokasi waktu kurang tepat.

Pada siklus 1 juga dilakukan pengamatan terhadap aktivitas siswa seperti yang tercantum pada tabel 2. 
Tabel 2. Data aktivitas siswa pada PBM

\begin{tabular}{llcc}
\hline No & \multicolumn{1}{c}{ Aktifitas yang diamati } & Jumlah siswa & Persentase \\
\hline 1 & Antusias mendengarkan penjelasan guru & 34 & 72,34 \\
2 & Melakukan diskusi dengan teman sebangku & 22 & 46,81 \\
3 & Menuliskan butir- butir penting & 17 & 36,17 \\
4 & Aktif melakukan diskusi kelas & 23 & 48,94 \\
& & Rerata: & $\mathbf{5 1 , 0 6}$ \\
\hline
\end{tabular}

Hasil tabel 2 menunjukkan bahwa hasil pengamatan klasikal mencapai rerata $51,06 \%$. Hal ini masih belum mencapai target yang diharapkan yaitu $80 \%$. Kegiatan mencatat butir- butir penting dan diskusi kelas masih sangat kurang. Untuk siklus II perlu ada motivasi pada kegiatan tersebut. Pada kegiatan klasikal pengamat menemukan beberapa perilaku siswa yang tidak relevan antara lain: (1) beberapa siswa tidak memperhatikan guru, mereka sibuk mengganggu teman lainnya, (2) beberapa siswa sibuk menggambar, (3) beberapa siswa tidak mau mecatat butir-butir penting, dan (4) beberapa siswa tampak tidak memperhatikan jalannya diskusi.

Setelah pembelajaran dilaksanakan, pada akhir siklus 1 diadakan tes untuk mengetahui hasil belajar siswa. Hasil tes menunjukkan bahwa jumlah siswa yang tuntas pada siklus I adalah 27 siswa atau 57\%. Masih ada 20 siswa yang tidak tuntas atau $43 \%$ siswa masih mencapai nilai kurang dari 75. Oleh karena itu perlu adanya perbaikanperbaikan pada siklus berikutnya. Dari analisa hasil ulangan (tabel tercantum dalam lampiran) diperleh empat tujuan pembelajaran belum mencapai ketuntasan $80 \%$ seperti yang ditargetkan.

Setelah diselesaikan siklus 1 , tim peneliti mengadakan pertemuan untuk membahas hal- hal positif maupun hal- hal negative yang muncul dalam siklus 1. Terdapat beberapa masukan untuk perbaikan- perbaikan pada siklus 2, yaitu (1) Pengamat menyarankan untuk menunjuk siswa yang berbeda dalam diskusi kelas agar diskusi tidak berlangsung monoton, (2) Pengamat menyarankan agar guru sesekali mendatangi tempat duduk siswa untuk melihat aktifitas siswa dari dekat, dan (3) Peneliti berinisiatif untuk memperbaiki media agar lebih menarik dan lebih sesuai dengan pengalaman sehari- hari siswa.

\section{Hasil Penelitian Siklus 2}

Kegiatan perencanaan pada siklus 2 ini peneliti menggunakan beberapa perangkat yang digunakan dalam siklus I. akan tetapi media yang digunakan diadakan perbaikan lagi. Dalam memperbaiki media juga dilakukan konsultasi dengan guru IPA yang dalam penelitian ini juga bertindak sebagai pengamat. Pelaksanaan tindakan dilaksanakan pada hari Rabu, tanggal 6 Maret 2013 dimulai pertemuan pertama siklus 2 kemudian dilanjutkan dengan pertemuan kedua pada hari Kamis, 7 Maret 2013. Pelaksanaan pembelajaran disesuaikan dengan RPP. Dari pembelajaran yang dilakukan diperoleh hasil aktivitas guru seperti pada Tabel 3.

Tabel 3. Data aktivitas guru pada PBM

\begin{tabular}{|c|c|c|c|}
\hline \multirow[t]{2}{*}{ No } & \multirow[t]{2}{*}{ Kegiatan } & \multicolumn{2}{|c|}{ Pertemuan } \\
\hline & & 1 & 2 \\
\hline \multirow[t]{4}{*}{1} & Pendahuluan (10 menit) & & \\
\hline & Menggali pengetahuan awal siswa, (5 menit) & 4 & 4 \\
\hline & Memotivasi siswa, (3 menit) & 3 & 3 \\
\hline & Menyampaikan tujuan pembelajaran, (2 menit) & 3 & 3 \\
\hline \multirow[t]{5}{*}{2} & Inti (60 menit) & & \\
\hline & $\begin{array}{l}\text { Membimbing siswa untuk berdiskusi dengan teman sebangku mengenai } \\
\text { materi yang diajarkan. }\end{array}$ & 4 & 4 \\
\hline & Memberikan penilaian keaktifan siswa dalam berdiskusi & 4 & 4 \\
\hline & Memberikan informasi yang sebenarnya mengenai materi yang diajarkan & 4 & 4 \\
\hline & Meminta siswa untuk mencatat butir- butir penting pada media & 3 & 3 \\
\hline \multirow[t]{3}{*}{3} & Penutup (10 menit) & & \\
\hline & Membimbing siswa membuat rangkuman materi yang diajarkan & 3 & 3 \\
\hline & Skor rata-rata & \multicolumn{2}{|c|}{3.50} \\
\hline
\end{tabular}


Hasil penelitian pada Tabel 3 dapat dilihat bahwa aspek- aspek yang diamati dalam PBM pada siklus 2 dilaksanakan dengan baik dan mengalami peningkatan dari siklus sebelumnya. Pada siklus ini guru bisa memperbaiki kekurangan pada siklus 1 .
Pada siklus 2 juga dilakukan oleah dua orang pengamat. Pembelajaran klasikal lebih baik dari siklus 1 . Untuk lebih jelasnya dapat diperhatikan pada Tabel 4.

Tabel 4. Data aktivitas siswa pada PBM

\begin{tabular}{|c|l|c|c|}
\hline No & \multicolumn{1}{|c|}{ Aktifitas yang diamati } & $\begin{array}{c}\text { Jumlah siswa } \\
\text { aktif }\end{array}$ & Persen-tase \\
\hline 1 & Antusias mendengarkan penjelasan guru & 43 & 91,49 \\
\hline 2 & Melakukan diskusi dengan teman sebangku & 39 & 82,98 \\
\hline 3 & Menuliskan butir- butir penting & 35 & 74,47 \\
\hline 4 & Aktif melakukan diskusi kelas & 41 & 87,23 \\
\hline Skor rerata: & & 84,04 \\
\hline
\end{tabular}

Hasil pengamatan belajar klasikal menunjukkan rerata $87 \%$. Hal ini menunjukkan kenaikan rerata dari siklus 1 yang hanya mencapai $63 \%$. Tercapainya rerata $87 \%$ telah memenuhi target yang ditentukan yaitu $80 \%$. Kenaikan rerata ini disebabkan adanya peningkatan aktifitas siswa dalam mendengarkan, berdiskusi dengan teman sebangku, mencatat dan melakukan diskusi kelas.

Hal ini sesuai dengan yang disampaikan oleh Nasution "Belajar akan lebih banyak terjadi jika media diintegrasikan dengan program instruksional yang tradisional, Siswa akan lebih mudah belajar secara efektif jika menggunakan media (multi media) dari pada pengajaran secara tradisional, Program-program multimedia atau tutorial audio untuk pembelajaran biasanya lebih disukai siswa bila dibandingkan dengan pengajaran tradisional" [3].

Oleh sebab itu "media diperlukan sebagai bentuk penguatan (reinforcement) pada siswa ke arah perubahan tingkah laku positip dan ke arah tujuan yang dikehendaki sebagai hasil dari proses pembelajaran" [5].

Pada akhir siklus 2 diadakan tes formatif untuk mengetahui hasil belajar siswa Hasil tes pada menunjukkan hasil belajar siswa yang mencapai rerata $84,26 \%$ dengan ketuntasan belajar $100 \%$. Dengan demikian indikator keberhasilan telah dicapai yaitu $100 \%$ siswa mengalami ketuntasan belajar.

Secara umu dapat dikatakan bahwa hasil penelitian tindakan ini terlihat adanya proses belajar siswa. Hal ini terlihat dari peningkatan aktifitas siswa dari siklus 1 yang mencapai 51,06\% dan mengalami peaningkatan pada siklus 2 menjadi $84,04 \%$. Peningkatan hasil belajar siswa juga terjadi dari siklus ke siklus. Pada siklus 1 persentase ketuntasan siswa hanya mencapai $68,77 \%$ dan terjadi peningkatan pada siklus 2 menjadi $84,26 \%$ sesuai yang ditargetkan. Peningkatan juga terjadi pada jumlah ketuntasan tujuan pembelajaran yang ditargetkan mencapai 80\%. Dari peningkatan proses belajar siswa dan hasil belajar siswa dan respon dari pengamat, menunjukkan bahwa media yang dikembangkan layak untuk diterapkan dalam pembelajaran pokok bahasan organisasi kehidupan.

\section{KESIMPULAN}

Media pembelajaran audio visual program microsoft power point untuk pokok bahasan organisasi kehidupan, dapat dikatan layak untuk digunakan. Hal ini dapat dilihat dari (1) Tanggapan dari guru IPA menyatakan layak, dan (2) Siswa termotivasi untuk belajar, tampak dari Hasil belajar siswa, yaitu ketuntasan $100 \%$ dengan perolehan nilai rerata 84,26\%; Efektif, tampak dari alokasi waktu yang digunakan sesuai dengan RPP; Efisien, tampak dari Proses belajar siswa yang diamati pengamat mencapai $84,04 \%$.

\section{DAFTAR PUSTAKA}

[1] Arikunto, Suharsimi dkk. 2007. Penelitian Tindakan Kelas. Bumi Aksara : Jakarta.

[2] Hamalik, Oemar, (1994). Media Pendidikan. (cetakan ke-7). Bandung: PT. Citra Aditya Bakti.

[3] Nasution, Zulkarimein. 1984. Media Dalam Pembelajaran, Jakarta: Pustekkom Dikbud \& CV. Raja Wali

[4] Sadiman, Arif.S. dkk. 1993. Media Pendidikan. Pengertian, Pengembamngan Dan Pemanfaatannya. Jakarta: Raja Grafindo Persada.

[5] Sudjana, N. dan Rivai, A. (1990). Teknologi Pengajaran. Bandung : CV Sinar Baru. 